\title{
Child sexual abuse: increasing pandemic incidence
}

\author{
Fabian Danilo Unigarro Ramírez ${ }^{(D)}$, Modesto Leite Rolim Neto
}

School of Medicine, Federal University of Cariri - UFCA, Barbalha, Brazil

\section{$\varnothing$}

Modesto Leite Rolim Neto,

School of Medicine

Universidade Federal do Cariri (UFCA).

Rua Divino Salvador, 284, Rosário,

Barbalha, Ceará 63180000, Brazil Phone: (+55 88) 999042979)

Email: modesto.neto@ufca.edu.br

Edited by:

Marcelo Moraes Valença

\section{Keywords:}

Child

Sexual Abuse

Public Health

SARS-CoV-2

Violence.

\begin{abstract}
Introduction: The increase of violence against children is characterized as a serious public health problem. The media has continuously reported cases of: rape perpetrated against children, increased violence against this age group and alarming epidemiological data resulting from the isolation of the pandemic by SARS-CoV-2.
\end{abstract}

Methods: Studies were identified using large-circulation international journals found in two electronic databases: Scopus and Embase.

Results: Cases of harassment, rape, manipulation of the child's genitals, oral, anal or genital penetration, pedophilia, exploitation, dissemination of erotic images of children in social networks, exhibitionism, masturbation, Voyeurism and incestuous abuse are classified as child sexual abuse. The numbers of legal abortions in child and adolescent victims of rape tends to increase a 100\% taking into account the in the first cases of 2020.

Conclusion: discussions for the implementation of public policies and healthcare for children victims of sexual abuse are important for prevention, treatment, rehabilitation and reintegration into the society, considering all the sequel that this vulnerable group acquires after the crime. 
solation and social distancing are measures to prevent the transmission of the new coronavirus (SARS-CoV-2). This microorganism causes COVID-19 disease, and show relevant and worrisome morbidity and mortality rates worldwide. ${ }^{1-3}$ The isolation resulted in the closure of several sectors including shops, schools, restaurants and industries, which contributes to the families staying longer in their homes. ${ }^{2,4,5}$ These measures have contributed to the increase of violence against children.

Violence is characterized as a serious public health problem. Given this, The World Health Organization (WHO) classifies violence based on the act perpetrated, in physical, psychological, sexual, deprivation, and neglect. ${ }^{6}$ Sexual violence is one of the most aggressive forms as it generates more damage to the victim. ${ }^{7.9}$ The media has continuously reported cases of: rape perpetrated against children, increased violence against this age group and alarming epidemiological data resulting from the isolation of the pandemic by SARS-CoV-2. $1,10,11$

Cases of harassment, rape, manipulation of the child's genitals, oral, anal or genital penetration, pedophilia, exploitation, dissemination of erotic images of children in social networks, exhibitionism, masturbation, Voyeurism and incestuous abuse are classified as child sexual abuse. ${ }^{12.14} 219.717$ cases of violence against children were reported in Brazil between 2015 and 2017. $26.42 \%$ of these are CSA cases, conditions that harm the child's mental, physical, moral and social health. ${ }^{15}$ During the pandemic, these numbers increased on an average of $20 \%$, making the topic relevant in the discussions about the creation and implementation of prevention policies. ${ }^{4}$ Despite this, the numbers of legal abortions in child and adolescent victims of rape tends to increase a $100 \%$ taking into account the 24 in the first cases of 2020 in Brazil. ${ }^{16}$

A 10-year-old girl who was raped by her uncle and allegedly by her grandfather, was admitted to a hospital with abdominal pain. After medical evaluations, a pregnancy of weeks was discovered and subsequently the preparation and cares for abortion began. ${ }^{17}$ Given this, it is notorious the misuse of power of the responsible for the crime, who feel on the right to perpetrate sexual violence against a child. $11,18,19$

Taking into account that, in such cases, the legislation concerns the right to terminate pregnancy. ${ }^{20}$ Therefore, it is essential that population know about prevention and orientation measures in cases of child sexual abuse, such as: calling public authorities, dial 100 (violation of human rights), dial 190 (civil police), taking the victim to the nearest emergency department, taking preventive cares against STls, knowing about procedures related to pregnancy stemming from rape and treatment of injuries, laboratory tests, referral to the Guardianship Council, refer the child to social assistance. ${ }^{21,22}$

Therefore, discussions for the implementation of public policies and healthcare for children victims of sexual abuse are important for prevention, treatment, rehabilitation and reintegration into the society, considering all the sequel that this vulnerable group acquires after the crime.

\section{Acknowledgements}

The authors would like to thank the Research Group: Suicidology - Universidade Federal do Ceará (UFC) and Brazilian National Council for Scientific and Technological Development (CNPq) - institution linked to the Brazilian Department of Science, Technology and Scientific Writing Lab, Medicine School - Universidade Federal of Cariri (UFCA).

\section{Funding}

The Research Group: Suicidology - Universidade Federal do Ceará (UFC) and Brazilian National Council for Scientific and Technological Development (CNPq) - institution linked to the Brazilian Department of Science, Technology and Innovation to encourage research in Brazil.

\section{Conflict of interests}

The authors declare that they have no competing interests.

Fabian Danilo Unigarro Ramírez

https://orcid.org/0000-0003-1753-4044

Modesto Leite Rolim Neto

https://orcid.org/0000-0001-9379-2120

\section{References}

1. Marques E, Moraes C, Hasselmann M, Deslandes S and Reichenheim M. A violência contra mulheres, crianças e adolescentes em tempos de pandemia pela COVID-19: panorama, motivações e formas de enfrentamento. Cad Saúde Pública 2020;36(4):e00074420 Doi:10.1590/0102-311x00074420

2. Duarte $M D Q$, Santo MADS, Lima CP, Giordani JP and Trentini CM. COVID-19 e os impactos na saúde mental: uma amostra do Rio Grande do Sul, Brasil. Ciênc. saúde coletiva 2020;25(9):3401-3411 Doi:10.1590/141381232020259.16472020

3. Rafael RMR, Neto M, de Carvalho MMB, David HMSL, Acioli $S$ and de Araujo Faria MG. Epidemiologia, 
políticas públicas e pandemia de Covid-19: o que esperar no Brasil?[Epidemiology, public policies and Covid-19 pandemics in Brazil: what can we expect?] [Epidemiologia, políticas públicas y la pandémia de Covid-19 en Brasil: que podemos esperar?]. Rev enferm UERJ 2020;28:49570 Doi:10.12957/ reveri.2020.49570

4. Ghosh R, Dubey M, Chatteriee S and Dubey S. Impact of COVID -19 on children: special focus on the psychosocial aspect. Minerva Pediatr 2020;72(3):226235 Doi:10.23736/s0026-4946.20.05887-9

5. Natividade MDS, Bernardes K, Pereira M, Miranda SS, Bertoldo J, Teixeira MDG, ... Aragão E. Distanciamento social e condições de vida na pandemia COVID-19 em Salvador-Bahia, Brasil. Ciência \& Saúde Coletiva 2020;25(9):3385-3392

Doi:10.1590/1413 81232020259.22142020

6. WHO. Joint Leaders' statement - Violence against children: A hidden crisis of the COVID-19 pandemic [Internet]. Who.int: World Health Organization: WHO; 2020; 2021 Available from: https://www.who. int/news/item/08-04-2020-joint-leader-s-statement-violence-against-children-a-hidden-crisis-of-the-covid-19pandemic.

7. Fonseca MdCF, Setubal CB and Costa LF. Adulto autor de violência sexual: Estudo exploratório de avaliação de risco de reincidência. Gerais: Revista Interinstitucional de Psicologia 2019;12(2):389-409 Doi:10.36298/ gerais2019120213

8. Nonato LOF, Peres AM, Khalaf DK, Souza MARD, Figueiredo KC and Lapierre J. Estratégias de gerenciamento na Atenção Primária à Saúde em territórios de vulnerabilidade social expostos à violência. Rev Esc Enferm USP 2020;54(e03608 Doi:10.1590/ s1980-220x2018054903608

9. Silva AFd, Estrela FM, Soares CFS, Magalhães JRFd, Lima NS, Morais AC, . . . Lima VLdA. Elementos precipitadores/intensificadores da violência conjugal em tempo da Covid-19. Ciênc. saúde coletiva 2020;25(9):3475-3480 Doi: 10.1590/1413. 81232020259.16132020

10. Oliveira J. Abortos legais em hospitais referência no Brasil disparam na pandemia e expõem drama da violência sexual [Internet]. EL PAÍS; 2020 Available from: https://brasil.elpais.com/brasil/2020-08-30/abortoslegais-em-hospitais-referencia-no-brasil-disparam-napandemia-e-expoem-drama-da-violencia-sexual.html

11. BBC. Quem abusa de criança não tem transtorno mental, só se sente no direito [Internet]. G1; 2020 cited 2021. Available from: https://g 1.globo.com/ciencia-esaude/noticia/2020/09/20/quem-abusa-de-criancanao-tem-transtorno-mental-so-se-sente-no-direito.ghtml
12. Araujo G, Ramos M, Zaleski T, Rozin L and Conceição Sanches $L$. Determinantes da violência sexual infantil no estado do Paraná-Brasil. Rev Espaço para a Saúde 2019;20(2):42-54 Doi:10.22421/151771302019v20n2p42

13. Ferreira CLS, Côrtes MCJW and Gontijo ED. Promoção dos direitos da criança e prevenção de maus tratos infantis. Ciênc. saúde coletiva 2019;24(1 1):3997-4008 Doi: 10.1590/1413-812320182411.04352018

14. Santos LF, Costa MMD, Javae ACRDS, Mutti CF and Pacheco LR. Fatores que interferem no enfrentamento da violência infantil por conselheiros tutelares. Saúde Debate 2019;43(120):137-149 Doi:10.1590/01031104201912010

15. Saúde MD. Boletim Epidemiológico. In: Saúde SVe, editor.: Secretaria de Vigilância em Saúde; 2018.

16. ESG. Menina de 11 anos queengravidou após estuprono ES tem gestação interrompida [Internet]. ES: G1 Globo; 2020 cited 2021. Available from: https://g1.globo. com/es/espirito-santo/noticia/2020/09/04/meninade-11-anos-que-engravidou-apos-estupro-no-es-temgestacao-interrompida.ghtml.

17. Magenta M and Alegretti L. Brasil registra 6 abortos por dia em meninas entre 10 e 14 anos estupradas [Internet]. BBC; 2020 [Available from: https://g 1 .globo. com/ciencia-e-saude/noticia/2020/08/17/brasilregistra-6-abortos-por-dia-em-meninas-entre-10-e-14anos-estupradas.ghtml.

18. Silva SBdJ, Conceição HNd, Câmara JT, Machado RS, Chaves TS, Moura DES, . . . Moura LRP. Perfil das notificações de violência contra crianças e adolescentes. Rev enferm UFPE on line 2020;14:e244171 Doi:10.5205/1981-8963.2020.244171

19. Teixeira JNDS, Resende $A C$ and Perissinotto R. Vitimização e Psicopatia em Autores de Violência Sexual contra Crianças e Adolescentes. Aval psicol 2020;19(2):123-131 Doi:10.15689/ ap.2020.1902.02

20. Bolsonaro JM. LEI No 13.964 DE 24 DE DEZEMBRO DE 2019. In: Jurídicos SPA, editor. Diário Oficial: Secretaria-Geral; 2019.

21. Antunes J, Machado Í and Malta D. Fatores de risco e proteção relacionados à violência intrafamiliar contra os adolescentes brasileiros. Rev Bras Epidemiol 2020;23(1):e200003

Doi:10.1590/1980549720200003.supl. 1

22. Oliveira NFD, Moraes CLD, Junger WL and Reichenheim ME. Violência contra crianças e adolescentes em Manaus, Amazonas: estudo descritivo dos casos e análise da completude das fichas de notificação, 20092016. Epidemiol Serv Saúde 2020;29(1):e2018438 Doi:10.5123/s1679-49742020000100012 